\title{
Small-scale distribution of the mesozooplankton in a tropical insular system
}

\author{
Renata Polyana de Santana Campelo ${ }^{1,3 *}$, Xiomara Franchesca Garcia Diaz ${ }^{1}$, Gleice Santos ${ }^{1}$, Pedro \\ Augusto Mendes de Castro Melo ${ }^{1}$, Mauro Melo Junior ${ }^{2}$, Lucas Guedes Pereira Figueiredo ${ }^{1}$, Andrea \\ Pinto Silva ${ }^{1}$, Luis Ernesto Arruda Bezerra², Manuel de Jesus Flores Montes ${ }^{1}$, Sigrid Neumann- \\ Leitão ${ }^{l}$
}

\begin{abstract}
${ }^{1}$ Universidade Federal de Pernambuco, Centro de Tecnologia e Geociências Museu de Oceanografia, Laboratório de Zooplâncton. (Av. Arquitetura s/n, Cidade Universitária, 50.740-550, Recife, Pernambuco, Brazil)

${ }^{2}$ Universidade Federal Rural de Pernambuco Departamento de Biologia, Laboratório de Ecologia de Plâncton.

(Rua Dom Manuel de Medeiros, s/n, Dois Irmãos, 52.171-900, Recife, Pernambuco, Brazil)

${ }^{3}$ Universidade Federal do Ceará Instituto de Ciências do Mar

(Av. da Abolição, 3207, Meireles, 60165-081, Fortaleza, Ceará, Brazil)
\end{abstract}

*Corresponding author: renatapolyanadesantanacampelo@gmail.com

\section{Abstract}

In the present work, spatial and seasonal fluctuations of the abundance and diversity of mesozooplankton are presented, with special attention being given to copepod assemblages from coastal area of the Fernando de Noronha Archipelago (FNA) (3 50 '24"S and $\left.32^{\circ} 24^{\prime} 48^{\prime \prime} \mathrm{W}\right)$. Sampling was carried out during the dry and rainy seasons of two consecutive years (July and December 2013) and (June and November 2014). A total of 37 mesozooplankton taxa were recorded, being the copepods the most diversified group (15 taxa). The Subclass Copepoda dominated in both periods sampled, comprising $53 \%$ and $86 \%$ of the total abundance in the dry and rainy season respectively. The species considered abundant were: Calanopia americana, Undinula vulgaris, Oithona plumifera and Corycaeus speciosus. The rainy season favored a significant increase in the abundance of mesozooplankton and copepods. However, a low value of the ShannonWiener diversity index was observed in this same seasonal period. This was explained by the dominance of the species $C$. americana and $U$. vulgaris in the studied area. Spatial differences have not been verified. The copepod assemblages was composed mostly by species considered as predator-carnivours of greater importance on the pelagic trophic web, indicators of oligotrophic conditions and components of a major portion of fish food items. Thus, we suggest that a spatially homogeneous mesozooplankton community characterizes the coastal area of Fernando de Noronha Archipelago with variations related mainly to the seasonal factor.

Descriptors: Community structure, Copepoda, Sazonality, Functional traits.

\section{REsumo}

Neste presente trabalho, são apresentadas as flutuações espacial e sazonal da abundância e diversidade do mesozooplâncton, com especial atenção para assembleia de copépodes da área costeira do Arquipélago de Fernando de Noronha (AFN) ( $3^{\circ} 50^{\prime} 24^{\prime \prime} \mathrm{S}$ and $\left.32^{\circ} 24^{\prime} 48^{\prime \prime} \mathrm{W}\right)$. A amostragem foi realizada durante as estações seca e chuvosa de dois anos consecutivos (julho e dezembro de 2013) e (junho e novembro de 2014). Um total de 37 taxa do mesozooplâncton foram registrados, sendo os copépodes o grupo mais diversificado (15 taxa). A Subclasse Copepoda dominou em ambos os períodos amostrados, com valores de abundância relativa equivalentes a $53 \%$ e $86 \%$, respectivamente, nas estações seca e chuvosa. As espécies consideradas abundantes foram: Calanopia americana, Undinula vulgaris, Oithona plumifera e Corycaeus speciosus. A estação chuvosa favoreceu um aumento significativo na abundância do mesozooplâncton e copépodes. No entanto, um baixo valor do índice de diversidade de Shannon-Wiener foi observado para este mesmo período sazonal. Isso foi explicado pelo domínio das espécies C. americana e $U$. vulgaris na área estudada. Diferença espacial não foi verificada. A assembleia de copépodes apresentou um maior número de espécies consideradas carnívoro-predador de grande importância na teia trófica pelágica, indicadoras de condições oligotróficas e componente de grande porção dos itens alimentares dos peixes. Assim, sugerimos que a área costeira do Arquipélago de Fernando de Noronha é caracterizada por uma comunidade do mesozooplâncton espacialmente homogênea, onde as mudanças observadas estão principalmente relacionadas ao fator sazonal.

Descritores: Estrutura da Comunidade, Copepoda, Sazonalidade, Características funcionais. 


\section{INTRODUCTION}

The zooplankton community plays a key role in the pelagic environment including the export of ocean surface carbon, energy transfer and organic matter to higher trophic levels, influencing primary producers (top-down effect) and predators (Falkowski et al., 1998; Barton et al., 2013).

Spatial and seasonal patterns of species distribution have motivated ecological research (Gause, 1934; Hutchinson, 1957). Understanding the processes that create these patterns has become increasingly important in the face of continuing threats of habitat destruction, pollution, species invasion and climate change (Robinson et al., 2011). Thus, the driving processes of the spatial distribution of organisms (local topography, current patterns, winds and physico-chemical characteristics of water masses) can provide insights into the possible mechanisms responsible for the complexity and maintenance of natural diversity and provide critical information for conservation priorities (Cowie and Holland, 2006).

In tropical seas, the seasonal dynamics of zooplankton ecological attributes are difficult to identify and are much less marked than those observed in temperate aquatic ecosystems (Dias et al., 2010). The zooplankton community structure of the Brazilian Northeastern region is directly influenced by rainy and dry periods and regional oceanographic phenomena (Neumann-Leitão et al., 1999). In addition to abiotic factors (seasonality and spatiality), the structure and composition of ecosystems are governed by biotic factors inherent to community such as the life cycles of organisms, migration, reproductive strategies, feeding approach, size and intra-interspecific relationships (Björnberg, 1981). Some zooplankton species, with well known tolerance levels to different environmental conditions can be used to describe the main characteristics of the water masses in which they occur (Wickstead, 1979; Rice and Stewart, 2016).

Despite their important in marine food web, few papers have been published about zooplankton in tropical coastal marine waters of Northeastern Brazil (NeumannLeitão et al., 1999; Neumann-Leitão et al., 1999; 2008) and to insular milieus (Mafalda Jr. et al., 2007; Diaz et al., 2009; Larrazabal et al., 2009; Melo et al., 2012). Insular environments in tropical oceans are hotspots for pelagic fauna, amidst the most nutrient-poor waters of the Atlantic Ocean, where occurs intensive fisheries. Analyses of species-diversity patterns of remote islands have been crucial to the development of ecological processes enriching production and to envisage the health quality of these environments.

In ocean, the holoplankton dominates numerically (Neumann-Leitão et al., 2008), and among all taxa, the copepods correspond to the most abundant (60 to $90 \%$ of the total abundance of zooplankton) and diverse group (Piontkovski et al., 2003). Furthermore, copepods play an important role in the functioning and maintenance of marine ecosystems. Thus the identification of functional groups based on species with similar responses to ecosystem functions and/or similar response to environmental conditions is a pressing need (Benedetti et al., 2015).

In spite of the above mentioned, our hypothesis was that abundance and diversity attributes of the mesozooplankton community fluctuate spatial and seasonally in a tropical insular system. Thus, the main objectives of our study are (i) To describe seasonal and spatial variations in the mesozooplankton community in a tropical oceanic Archipelago in Brazilian Northeastern; (ii) To provide data on seasonal and spatial changes of abundance and diversity of the main group (copepods); and (iii) To identify the functional traits of dominant copepod species from this tropical area.

\section{MATERIAL AND METHODS}

\section{STUDY AREA}

The Fernando de Noronha Archipelago (FNA) (Figure 1) lies in a National Marine Park (created by Decree No. 96.693 of September 14, 1988), as well as a State protected area (created by Decree 92.755 of June 5, 1986) (Almeida, 1955), being located in the Equatorial Atlantic (Tropical). The park covers 21 islands, islets and rocks, encompassing part of the FNA and a chain of seamounts located at $3^{\circ} 50$ ' $24^{\prime \prime} \mathrm{S}$ and $32^{\circ} 24^{\prime} 48^{\prime \prime} \mathrm{W}$. The FNA is located approximately $545 \mathrm{~km}$ from the capital of Pernambuco (Recife), $2.600 \mathrm{~km}$ from the African coast and $360 \mathrm{~km}$ from the South American continent (Lira et al., 2014).

Due to the morphological configuration of the main island, two coasts have been formed opposite to each other, one on the southeast side and the other on the northwest side. The area is characterized by the tropical climate (Köeppen, 1948) having two well-defined seasons: a dry (August-February) and a rainy season (March to July). The mean annual rainfall is about $1.400 \mathrm{~mm}$, and the annual mean temperature $25^{\circ} \mathrm{C}$ (Serafini et al., 2010). The Archipelago is subject to a complex system of currents and 


\section{SOUTH AMERICA}

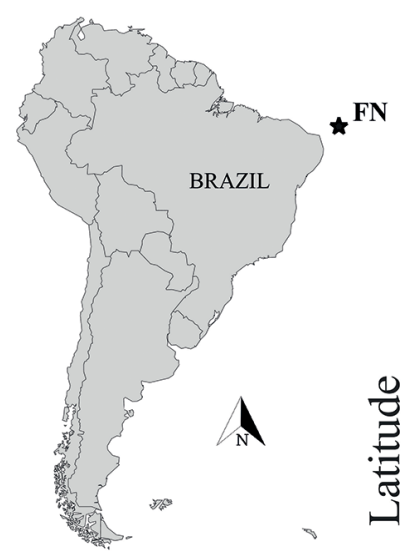

Stations:

01 - Santo Antônio Port

02 - Cachorro Beach

03 - Conceição Beach

04 - Cacimba do Padre

05 - Golfinhos Bay

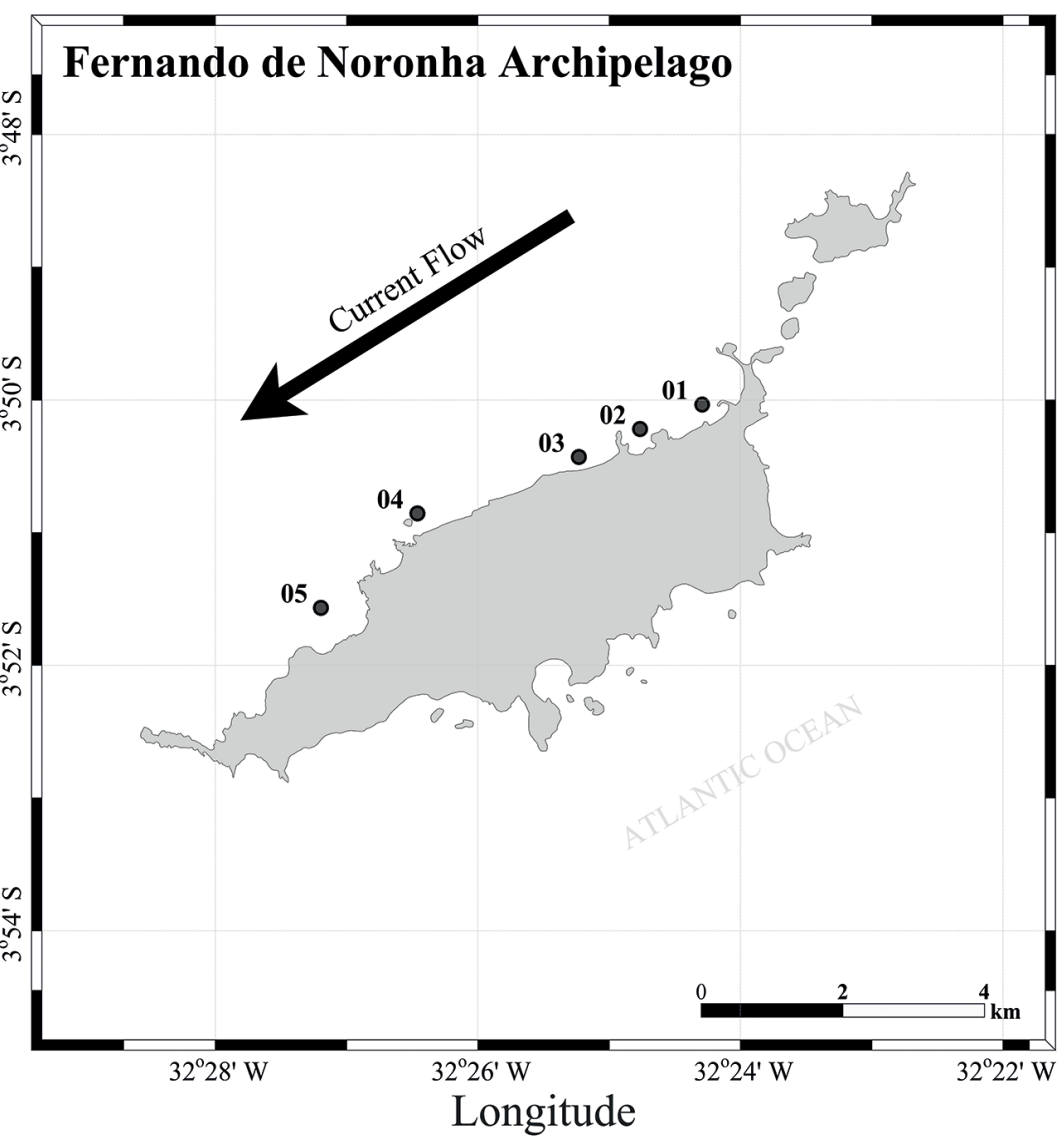

Figure 1. Study area showing the collection stations off the Fernando de Noronha Archipelago ( $3^{\circ} 50^{\prime} 24^{\prime \prime}$ S and $32^{\circ} 24^{\prime} 48^{\prime \prime}$ W), State of Pernambuco, Northeastern Brazil. Santo Antonio Port (1), Cachorro Beach (2), Conceição Beach (3), Cacimba do Padre (4) and Golfinhos Bay (5).

undercurrents that flow mainly in an East-West direction along the equator, usually under the influence of the South Equatorial Current (SEC) in the surface layer of the water column. The prevailing winds are the southeasterly trades, varying to northeasterly, with a mean intensity of $4.8 \mathrm{~m}$ $\mathrm{s}^{-1}$, from the surface to the level of $750 \mathrm{mb}$ (Assunção et al., 2016).

\section{SAMPLING STRATEGY}

Sampling was carried out during four diurnal oceanographic expeditions along the western coast of FNA during the dry and rainy seasons of two consecutive years (July and December 2013 and June and November 2014). A total of 19 samples were collected. Five stations were determined being to the north: Santo Antonio Port (1), Cachorro Beach (2) and Conceição Beach (3) and to the south: Cacimba do Padre (4) and Golfinhos Bay (5) (Figure 1). The stations presented different local depths (ranging from 2 to 30 meters, with a mean of $16.6 \mathrm{~m}$ ) due to variations in the tide and the climatic periods throughout the study.

\section{SAMPLING AND LABORATORY ANALYSES}

Zooplankton samples were collected by horizontal subsurface hauls that were performed with a cylindricalconical net (mouth area $0.6 \mathrm{~m}^{2}$, mesh size $300 \mu \mathrm{m}$ ) during 10 minutes. To obtain the water volume filtered, a flowmeter was coupled at the net mouth. After collection, the samples were transferred to plastic bottles and immediately preserved in formaldehyde solution (4\%), buffered with sodium tetraborate.

In the laboratory, the samples were fractionated in aliquots of $1 / 32$ or $1 / 64$, using a Motoda splitter (Omori \& Ikeda, 1984) provided that a minimum number of 200 individuals were analyzed (Frontier, 1981). The specimes were identified and inspected under a Zeiss Discovery V8 stereomicroscope.

The copepods identification mainly followed Björnberg (1981), Bradford-Grieve et al. (1999) and Dias 
and Araújo (2006). The overall abundance of each species was estimated for juvenile and adult copepodites. All the specimens found were deposited in the zooplankton collection of the Museum of Oceanography at UFPE.

In this study, only the species of copepods were classified according to their functional characteristics, such as: body size $(<1100 \mu \mathrm{m} ; 1000-1300 \mu \mathrm{m} ; 1500-3300$ $\mu \mathrm{m}$ and $>1700 \mu \mathrm{m}$ ), trophic group (herbivorous, suspensivores, omnivorous, detritivores and carnivorous), spawning strategy (broadcast spawner and sac-spawner) and vertical distribution (epipelagic, mesopelagic, epipelagic to mesopelagic and epipelagic to bathypelagic). The functional characteristics were obtained from the literature (Boltovskoy, 1981; 1999; Benedetti et al., 2015; Pomerleau et al., 2015).

\section{STATISTICAL ANALYSIS}

The Shannon-Wiener index $\left(\mathrm{H}^{\prime}\right)$ was applied on copepod assemblages as the measure of diversity. Main effects ANOVA was used to analyze the first-order (non-interactive) effects of multiple categorical independent variables (spatial and seasonal) on biotic variables (abundance of mesozooplankton, abundance of copepods, dominant species of copepods (with more than $2 \%$ of total abundance) and Shannon-Wiener diversity index).

The heterogeneity of variances was verified through the Levene test and normality tested using the Shapiro Wilk's test. The data were transformed by the Log $(\mathrm{X}+1)$ when necessary. Multivariate procedures included: (i) Permutational Multivariate analysis of variance (PERMANOVA) (Anderson, 2001; Mcardle and Anderson, 2001) was performed (with 999 permutations) based on the dissimilarity of Bray-Curtis (data transformed with $\log X+1)$. This analysis was used to determine whether there were significant differences in the structure of the mesozooplankton community between the dry and rainy seasons (seasonal factor) and among sampling stations (spatial factor). The interaction of these two factors was also tested. Only species that presented more than $2 \%$ of relative abundance were considered in this analysis. (ii) Multi-dimensional scaling (MDS) was used to represent the Bray-Curtis matrix graphically in a twoaxis space (Sarmento and Santos, 2012). The significance of the PERMANOVA was assessed by the $p$ value. (iii) In case of significant differences, SIMPER (Similarity of percentages) test was used to identify the taxa that contributed most to the dissimilarity between the groups. (iv) Classification (cluster analysis) of the sample-copepod species data matrix based on the Sorensen coefficient and weighted pair group method was used with the averaging clustering method built on four functional characteristics (body size, trophic group, spawning strategy and vertical distribution).

The indicator value analysis (Indval) was calculated to classify the fidelity of taxa in relation to the tested factors (seasonal and spatial), and tests for the statistical significance of the associations by permutation (Dufrêne and Legendre, 1997; Legendre and Legendre, 1998). The values varied from $0 \%$ (no indication) to $100 \%$ (perfect indication). It was considered those taxa occurring with more than $20 \%$ of frequency of occurrence. Only the taxa that presented values of indicators (Indval) $\geq 50 \%$ were considered indicators of the factors tested. The indicator value (Indval) of a species has been used to show species status as ecological indicator.

The Shannon-Wiener index, SIMPER analyze, MDS and PERMANOVA were applied using the software Primer_v.6. The Main effects ANOVA test was calculated using the software STATISTICA 7.0. The Indval value was calculated using the software R-Studio (available at https://cran.r-project.org/) within the R-Studio (v.0.99) user interface (available at http://www.rstudio.com/). The level of significance was set at $p<0.05$ for all analyses. Parametric statistical analysis followed Zar (1996).

\section{RESULTS}

\section{SEASONAL VARIATION}

Altogether, 37 taxa were identified (Table 1). Holoplankton dominated with $97 \%$ of all taxa. In general, copepods dominated in both periods sampled, comprising $53 \%$ of the zooplankton community in the dry season and $86 \%$ in the rainy season (Figure $2 \mathrm{a}$ and $2 \mathrm{~b}$ ). 15 species of Copepoda where recorded (Table 1); the most abundant species were Calanopia americana, Undinula vulgaris, Oithona plumifera and Corycaeus speciosus (Figure 2c and $2 \mathrm{~d}$ ). Among the copepods, C. americana was considered dominant, representing 35\% (dry season) and 79.33\% (rainy season) of the total copepods (Figure 2c and 2d).

The second most abundant holoplankton group was Appendicularia, with $12.76 \%$ in the dry and $0.88 \%$ in the rainy season (Figure $2 \mathrm{a}$ and $2 \mathrm{~b}$ ). The meroplankton consisted of larval gastropods, with $4.59 \%$ in the dry and $1.25 \%$ in the rainy season and fish (eggs and larvae) with $2.17 \%$ in the dry and $5.81 \%$ in the rainy season (Figure $2 \mathrm{a}$ and $2 \mathrm{~b})$. 
Table 1. Total abundance of mesozooplankton (ind. $\mathrm{m}^{-3}$ ) identified in the stations: Santo Antonio Port (1), Cachorro Beach (2), Conceição Beach (3), Cacimba do Padre (4) and Golfinhos Bay (5) located on Fernando de Noronha Archipelago during the rainy and dry seasons of two consecutive years (July and December 2013 and June and November 2014). In bold type the copepod species considered dominant (Abundance $\geq 2 \%$ ).

\begin{tabular}{|c|c|c|c|c|c|c|c|c|c|c|}
\hline \multirow[b]{2}{*}{ Stations } & \multicolumn{5}{|c|}{ RAINY SEASON } & \multicolumn{5}{|c|}{ DRY SEASON } \\
\hline & 1 & 2 & 3 & 4 & 5 & 1 & 2 & 3 & 4 & 5 \\
\hline \multicolumn{11}{|l|}{ Taxa } \\
\hline Foraminifera (Others) & 0.00 & 0.00 & 9.82 & 19.71 & 0.45 & 1.13 & 0.01 & 2.30 & 4.60 & 1.91 \\
\hline Globigerinoides sp. & 0.50 & 0.00 & 0.00 & 0.00 & 0.00 & 0.00 & 0.00 & 0.00 & 0.00 & 0.00 \\
\hline Siphonophorae & 0.38 & 0.00 & 0.00 & 4.64 & 0.15 & 0.68 & 0.02 & 0.58 & 1.16 & 0.81 \\
\hline Bivalvia & 0.00 & 0.00 & 0.00 & 0.00 & 0.00 & 0.01 & 0.00 & 0.32 & 0.64 & 0.00 \\
\hline $\begin{array}{l}\text { Gastropoda } \\
\text { (Veliger and Juvenile) }\end{array}$ & 0.38 & 2.58 & 3.93 & 6.57 & 0.07 & 0.92 & 0.02 & 0.51 & 1.03 & 0.43 \\
\hline Bryozoa & 0.25 & 0.00 & 0.00 & 0.00 & 0.00 & 0.00 & 0.00 & 0.00 & 0.00 & 0.17 \\
\hline Polychaeta (Larvae) & 0.00 & 0.83 & 0.00 & 0.00 & 0.00 & 0.02 & 0.01 & 0.06 & 0.13 & 0.00 \\
\hline Ostracoda & 0.00 & 0.00 & 0.00 & 0.00 & 0.00 & 0.05 & 0.00 & 0.00 & 0.00 & 0.00 \\
\hline Calanoida & 0.00 & 0.00 & 2.95 & 0.00 & 0.00 & 0.00 & 0.00 & 0.00 & 0.00 & 0.00 \\
\hline Calanoida (Copepodite) & 3.05 & 5.81 & 0.00 & 105.12 & 3.71 & 0.45 & 0.05 & 0.00 & 0.00 & 0.55 \\
\hline Calanidae & 0.00 & 0.00 & 0.00 & 0.00 & 7.95 & 0.00 & 0.00 & 0.00 & 0.00 & 0.00 \\
\hline Undinula vulgaris & 5.41 & 6.08 & 2.95 & 13.53 & 1.74 & 1.41 & 0.07 & 0.81 & 1.62 & 0.85 \\
\hline Calocalanus pavo & 0.00 & 1.22 & 0.98 & 6.57 & 0.07 & 0.45 & 0.01 & 0.00 & 0.00 & 0.22 \\
\hline Calocalanus (Copepodite) & 0.00 & 1.55 & 0.00 & 0.00 & 3.62 & 0.00 & 0.00 & 0.00 & 0.00 & 0.00 \\
\hline Paracalanus aculeatus & 0.25 & 0.00 & 0.00 & 0.00 & 0.00 & 0.00 & 0.00 & 0.00 & 0.00 & 0.00 \\
\hline Acrocalanus longicornis & 5.20 & 20.73 & 14.73 & 6.57 & 0.00 & 0.45 & 0.00 & 0.00 & 0.00 & 0.00 \\
\hline Acrocalanus (Copepodite) & 0.00 & 0.00 & 0.00 & 6.57 & 0.07 & 0.00 & 0.00 & 0.00 & 0.00 & 0.11 \\
\hline Clausocalanus furcatus & 0.00 & 0.05 & 0.00 & 0.00 & 0.00 & 0.00 & 0.00 & 0.00 & 0.00 & 0.00 \\
\hline Euchaeta marina & 0.00 & 0.00 & 0.00 & 0.00 & 0.00 & 0.00 & 0.00 & 0.00 & 0.10 & 0.00 \\
\hline $\begin{array}{l}\text { Metridia spp. } \\
\text { (Copepodite) }\end{array}$ & 0.00 & 0.00 & 0.00 & 0.00 & 0.30 & 0.00 & 0.00 & 0.00 & 0.00 & 0.00 \\
\hline Centropages velificatus & 0.00 & 0.00 & 0.00 & 0.00 & 0.00 & 0.00 & 0.00 & 0.00 & 0.33 & 0.00 \\
\hline Candacia pachydactyla & 0.00 & 0.00 & 0.00 & 2.84 & 0.00 & 0.00 & 0.00 & 0.00 & 0.07 & 0.00 \\
\hline Calanopia americana & 25.14 & 84.52 & 50.08 & 519.03 & 0.52 & 1.63 & 0.12 & 0.14 & 0.28 & 1.56 \\
\hline Oithona plumifera & 1.01 & 1.66 & 2.95 & 6.57 & 0.22 & 3.47 & 0.26 & 0.63 & 1.26 & 0.91 \\
\hline Oncaea mediterranea & 0.00 & 0.00 & 0.00 & 0.00 & 0.00 & 0.00 & 0.00 & 0.00 & 0.01 & 0.00 \\
\hline Oncaea venusta & 0.63 & 0.29 & 0.98 & 0.00 & 0.07 & 0.69 & 0.04 & 0.02 & 0.04 & 0.32 \\
\hline Corycaeus speciosus & 0.50 & 3.25 & 0.00 & 2.32 & 0.60 & 2.27 & 0.17 & 0.08 & 0.16 & 1.07 \\
\hline Agetus flaccus & 0.00 & 0.00 & 0.00 & 0.00 & 3.62 & 0.00 & 0.00 & 0.00 & 0.00 & 0.00 \\
\hline Farranula gracilis & 2.29 & 9.90 & 5.89 & 28.60 & 0.22 & 2.31 & 0.07 & 0.08 & 0.15 & 0.86 \\
\hline Stomatopoda & 0.00 & 0.00 & 0.00 & 1.16 & 0.00 & 0.00 & 0.00 & 0.00 & 0.00 & 0.00 \\
\hline Decapoda & 0.84 & 0.00 & 0.00 & 0.00 & 0.00 & 0.00 & 0.00 & 0.00 & 0.00 & 0.00 \\
\hline Mysidacea & 0.00 & 0.00 & 0.00 & 0.00 & 0.00 & 0.47 & 0.00 & 0.00 & 0.15 & 0.00 \\
\hline Amphipoda & 0.00 & 0.00 & 0.00 & 0.00 & 0.00 & 0.00 & 0.00 & 0.00 & 0.05 & 0.00 \\
\hline Chaetognatha & 3.26 & 0.00 & 0.00 & 19.32 & 0.97 & 1.13 & 0.15 & 0.01 & 0.02 & 1.71 \\
\hline Flaccisagitta enflata & 0.00 & 0.00 & 0.00 & 0.00 & 0.07 & 0.00 & 0.00 & 0.00 & 0.00 & 0.43 \\
\hline Appendicularia & 0.38 & 0.00 & 7.86 & 0.00 & 1.27 & 4.08 & 0.07 & 0.00 & 0.00 & 4.06 \\
\hline Teleostei (Eggs and Larvae) & 40.96 & 1.66 & 6.87 & 13.14 & 0.00 & 1.13 & 0.06 & 0.00 & 0.00 & 0.88 \\
\hline Mean & 2.44 & 3.79 & 2.97 & 20.60 & 0.69 & 0.61 & 0.03 & 0.14 & 0.31 & 0.45 \\
\hline $\operatorname{STD}( \pm)$ & 7.76 & 14.18 & 8.63 & 86.10 & 1.59 & 1.00 & 0.05 & 0.41 & 0.82 & 0.80 \\
\hline
\end{tabular}




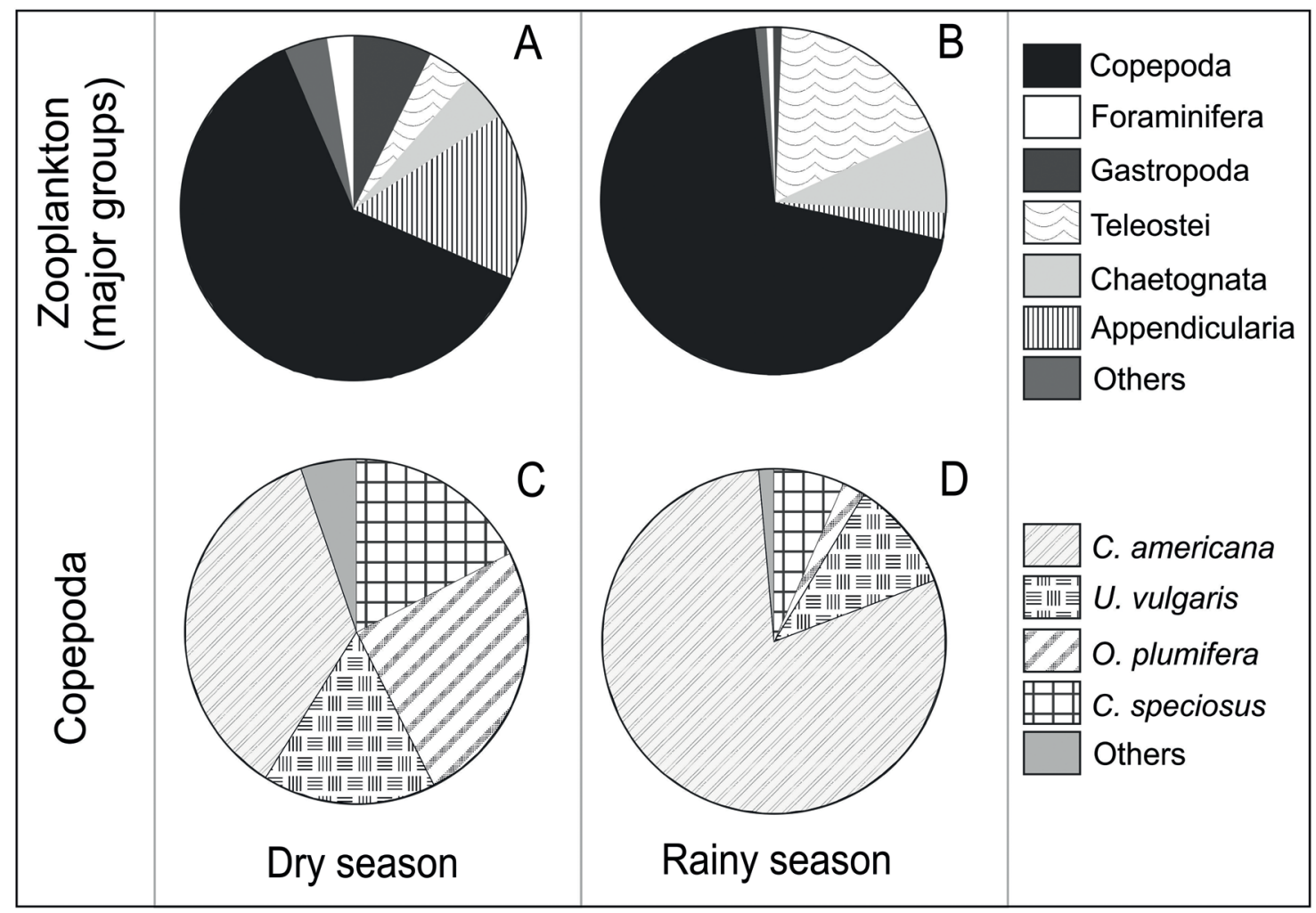

Figure 2. Relative abundance of the mesozooplankton community (abundance $>2 \%$ ) during the dry (A) and rainy (B) seasons. Relative abundance of the dominant copepod species (abundance $>2 \%$ ) in the dry season (C) and rainy season (D) from the months of July and December/2013 and June and November/2014 in the coastal area of the Fernando de Noronha Archipelago in northeastern Brazil.

The effect of seasonality on the total abundance of mesozooplankton, total abundance of copepods, Calanopia americana, Undinula vulgaris (dominant species copepods) and Shannon-Wiener diversity is illustrated in Figure 3a, 3b, 3c, $3 \mathrm{~d}$ and $3 \mathrm{e}$, respectively.

The mean abundance of mesozooplankton and of copepods for dry season were: $13.04 \pm 19.39$ ind. $\mathrm{m}^{-3} ; 7.53 \pm 14$ ind. $\mathrm{m}^{-3}$ and for rainy season: $72.83 \pm 73.02$ ind. $\mathrm{m}^{-3}$; $108.63 \pm 161.92$ ind. $\mathrm{m}^{-3}$ respectively (Table $2 \mathrm{~b}$ ). The Anova indicated the significant effect of the seasonal factor on the mean abundance of mesozooplankton $(F(1,13)=15.82$, $p$-level $=0.001)$ and mean abundance of copepods $(F(1$, 13) $=15.78$, -level $=0.001$ ) (Table 2a).

Among the copepod species considered to be dominants only $C$. americana $(\mathrm{F}(1,10)=23.39, p$-level $=0.006)$ and $U$. vulgaris $(\mathrm{F}(1,12)=17.73$, $p$-level $=0.001)$ responded to the seasonal factor (Table 2a), whose mean abundance value was significantly higher in the rainy season $97 \pm 123.93$ ind. $\mathrm{m}^{-3}$ and $\left(3.30 \pm 2.26\right.$ ind. $\left.\mathrm{m}^{-3}\right)$ respectively in comparison to dry season $3.84 \pm 9.79$ ind. $\mathrm{m}^{-3}$ and $\left(0.72 \pm 0.74\right.$ ind $\left.\mathrm{m}^{-3}\right)$ respectively (Table $2 \mathrm{~b}$ ).
The Shannon-Wiener diversity of copepods differed significantly between the seasonal periods investigated $(\mathrm{F}(1,13)=6.66, p$-level $=0.02)($ Table $2 \mathrm{a})$, presenting a higher mean diversity during the dry season $\left(2.19 \pm 0.57\right.$ bits.ind $\left.^{-1}\right)$ compared to the mean recorded in the rainy season $\left(1.46 \pm 0.69\right.$ bits.ind $\left.^{-1}\right)$ (Table 2b).

\section{SPATIAL VARIATION}

The mean abundance of mesozooplankton in stations 1, 2, 3, 4 and 5 were respectively: $28.52 \pm 21.58$ ind. $\mathrm{m}^{-3}, 35.69 \pm 63.88$ ind. $\mathrm{m}^{-3}, 61.56 \pm 50.13$ ind. $\mathrm{m}^{-3}$, $194.60 \pm 257.98$ ind. $\mathrm{m}^{-3}$ and $11.41 \pm 6.07$ ind. $\mathrm{m}^{-3}$ equivalent to: $14.15 \pm 17.02$ ind. $\mathrm{m}^{-3}$ at the station $1,33.96 \pm 61$ ind.m-3 at the station $2,44.36 \pm 38$ ind. $\mathrm{m}^{-3}$ at the station 3, 175.30 \pm 237.90 ind. $\mathrm{m}^{-3}$ at the station 4 and $7.29 \pm 8.28$ ind. $\mathrm{m}^{-3}$ at the station 5 (Figure 4a).

The Shannon-Wiener diversity had a higher mean numerical value at station 2 (Cachorro beach) and a lower value at station 4 (Cacimba do Padre) (Figure 4b). The 

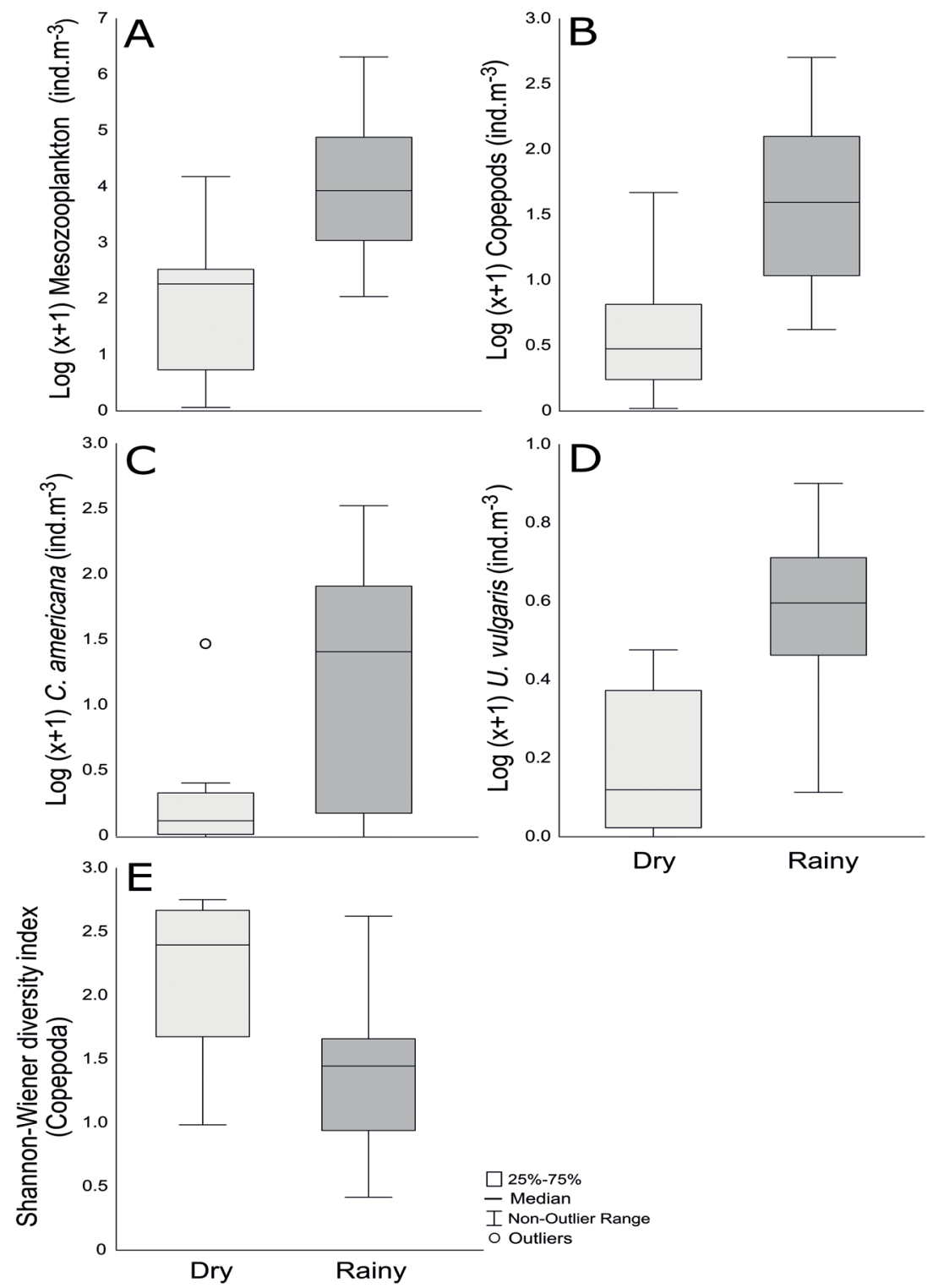

Figure 3. Box-Plot (median and quartiles) representing the $\log (\mathrm{X}+1)$ of: (A) Mesozooplankton (ind. $\left.\mathrm{m}^{-3}\right)$; B) copepods (ind. $\mathrm{m}^{-3}$ ); (C) C. americana (ind. $\mathrm{m}^{-3}$ ) and (D) U. vulgaris (ind. $\mathrm{m}^{-3}$ ) between the seasonal periods (DRY vs RAINY) in the coastal area of the Fernando de Noronha Archipelago in northeastern Brazil.

mean values of Shannon-Wiener diversity recorded for the stations 1, 2, 3, 4 and 5 were: $2.02 \pm 0.63$ bits.ind $^{-1}$, $2.09 \pm 0.43$ bits.ind $^{-1}, 2.03 \pm 0.62$ bits.ind $^{-1}, 1.19 \pm 0.86$ bits. ind $^{-1}$ and $1.95 \pm 0.86$ bits.ind $^{-1}$ respectively (Figure $4 \mathrm{~b}$ ).

There were no significant differences among the stations sampled in terms of total abundance of mesozooplankton, total abundance of copepods and ShannonWiener diversity.
All copepod species considered dominant: Calanopia americana (129.82 \pm 164 ind. $\left.\mathrm{m}^{-3}\right)$, Undinula vulgaris $\left(3.78 \pm 3.49\right.$ ind. $\left.\mathrm{m}^{-3}\right)$, Oithona plumifera $(1.95 \pm 3.11$ ind. $\left.\mathrm{m}^{-3}\right)$ and Corycaeus speciosus $\left(0.93 \pm 1.07\right.$ ind. $\left.\mathrm{m}^{-3}\right)$ also recorded numerically highest mean values at station four (Cacimba do Padre), but statistical differences were not verified among the sampling stations. The species Calanopia americana dominated spatially in both seasonal periods sampled, but its abundance values were 
Table 2. Main effects ANOVA results for abundance of: (i) Mesozooplankton; (ii) Copepods; (iii) Undinula vulgaris; (iv) Calanopia americana and (v) Shannon-Wiener diversity in response to the seasonal factor (as between dry vs rainy) and spatial factor (as between stations) on Fernando de Noronha Archipelago in northeastern Brazil.

\begin{tabular}{|c|c|c|c|c|c|c|c|c|c|}
\hline \multirow{2}{*}{$\begin{array}{l}\text { a) ANOVA } \\
\text { Source }\end{array}$} & \multicolumn{5}{|c|}{ (i) Mesozooplankton abundance } & \multicolumn{4}{|c|}{ (ii) Copepods abundance } \\
\hline & df & MS & $\mathrm{F}$ & $p$ & Source & df & MS & $\mathrm{F}$ & $p$ \\
\hline Spatial (ST) & 4 & 2.84 & 1.92 & 0.16 & Spatial (ST) & 4 & 0.54 & 1.67 & 0.21 \\
\hline Seasonal (S) & 1 & 23.38 & 15.81 & 0.001 & Seasonal (S) & 1 & 5.17 & 15.78 & 0.001 \\
\hline \multirow[t]{2}{*}{ Residual } & 13 & 1.47 & & & Residual & 13 & 0.32 & & \\
\hline & \multicolumn{4}{|c|}{$\begin{array}{c}\text { (iii) } \\
\text { Undinula vulgaris }\end{array}$} & & & \multicolumn{3}{|c|}{ Calanopia americana } \\
\hline Spatial (ST) & 4 & 0.38 & 1.78 & 0.19 & Spatial (ST) & 4 & 3.39 & 1.73 & 0.21 \\
\hline Seasonal (S) & 1 & 3.80 & 17.73 & 0.001 & Seasonal (S) & 1 & 23.39 & 11.96 & 0.006 \\
\hline Residual & 12 & 0.21 & & & Residual & 10 & 1.95 & & \\
\hline \multicolumn{10}{|c|}{ (v) Shannon-Wiener diversity $\left(\mathrm{H}^{\prime}\right)$} \\
\hline Spatial (ST) & 4 & 0.53 & 1.49 & 0.26 & & & & & \\
\hline Seasonal (S) & 1 & 2.38 & 6.66 & 0.02 & & & & & \\
\hline Residual & 13 & 0.35 & & & & & & & \\
\hline \multirow[t]{2}{*}{ b) BIOTIC VARIABLES } & & & \multicolumn{2}{|c|}{ Dry season } & \multicolumn{2}{|c|}{ Rainy season } & & & \\
\hline & & & Mean & SD & Mean & $\mathrm{SD}$ & & & \\
\hline $\begin{array}{l}\text { Total abundance of Zooplankton } \\
\text { (ind. } \mathrm{m}^{-3} \text { ) }\end{array}$ & & & 13.04 & \pm 19.39 & 126.13 & \pm 173.88 & & & \\
\hline $\begin{array}{l}\text { Total abundance of Copepods } \\
\text { (ind. } \mathrm{m}^{-3} \text { ) }\end{array}$ & & & 7.53 & \pm 14.00 & 108.63 & \pm 161.92 & & & \\
\hline Undinula vulgaris (ind. $\mathrm{m}^{-3}$ ) & & & 0.72 & \pm 0.74 & 3.30 & \pm 2.26 & & & \\
\hline Calanopia americana (ind. $\mathrm{m}^{-3}$ ) & & & 3.84 & \pm 9.79 & 97 & \pm 123.93 & & & \\
\hline Shannon-Wiener diversity $\left(\mathrm{H}^{\prime}\right)$ & & & 2.19 & \pm 0.57 & 1.46 & \pm 0.69 & & & \\
\hline
\end{tabular}

Significant $(p<0.05)-p$ values in bold.
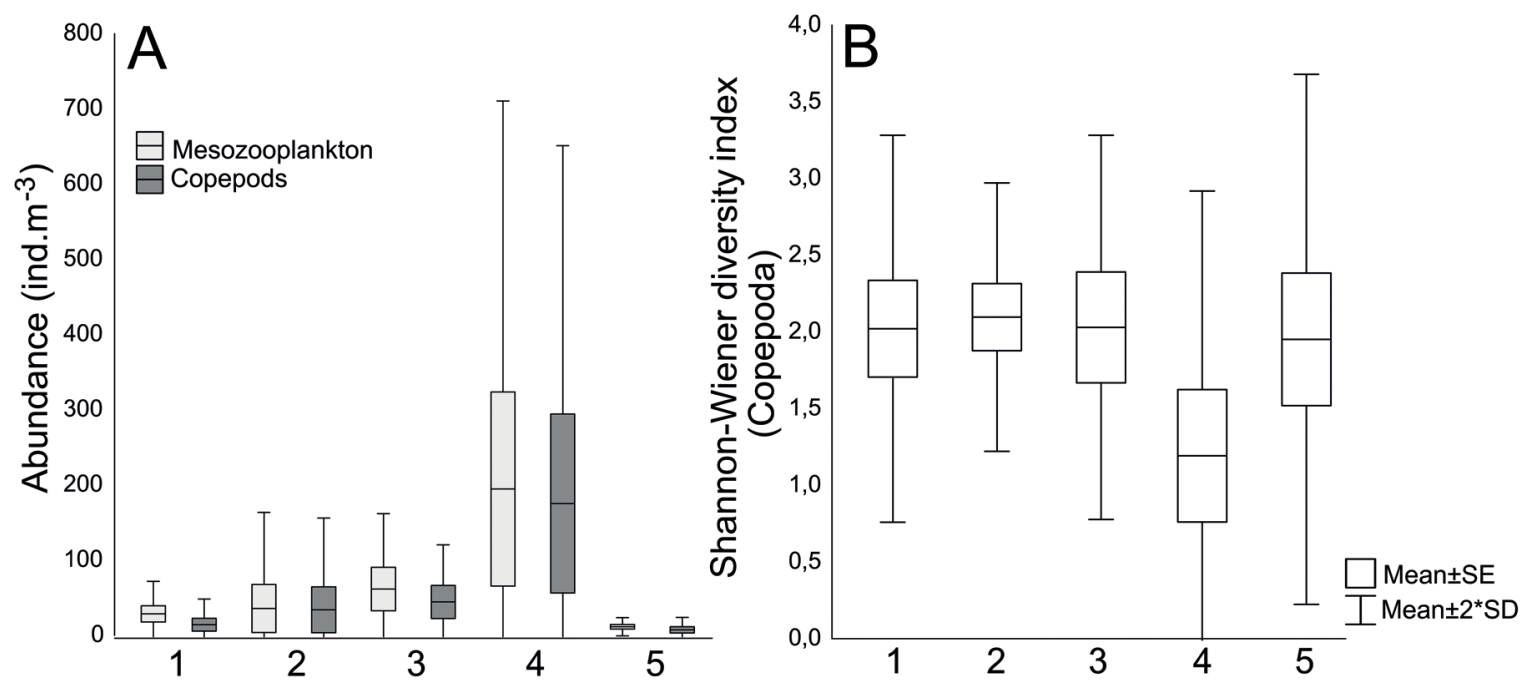

Figure 4. Box-Plot (mean and standard deviation) representing the spatial variation of: (A) Mesozooplankton (light gray) and Copepods (dark gray) and (B) Shannon-Wiener diversity index (for copepods) at stations: Santo Antonio Port (1), Cachorro Beach (2), Conceição Beach (3), Cacimba do Padre (4) and Golfinhos Bay (5) in the coastal area of the Fernando de Noronha Archipelago in northeastern Brazil. 
much higher in the rainy period (more than 250 ind. $\mathrm{m}^{-3}$ ) (Figure 5).

\section{MESOZOOPLANKTON COMMUNITY STRUCTURE}

MDS analyses indicated differences in the structure of the mesozooplankton community of the Fernando de Noronha Archipelago between dry and rainy seasons (Figure 6), but differences among the five sampling stations were not verified. The pattern illustrated in the MDS ordination was confirmed by PERMANOVA. Significant differences in the structure of the mesozooplankton community of the Fernando de Noronha Archipelago were detected between seasons (dry vs. rainy) $(p=0.02)$ (Table 3). The interaction between factors (stations $\mathrm{x}$ seasons) did not show statistical difference (Table 3). The observed differences between seasons were examined through of the average dissimilarity (SIMPER) among the two sets of data (mesozooplankton abundance), which was equivalent to $76.84 \%$. The greatest dissimilarity between dry and rainy seasons is generated by Calanopia americana (as shown in Table 4).

\section{INDICATOR VALUE AND FUNCTIONAL TRAITS}

The rainy season was represented by two significant indicator (characteristic) species. Indicator values (Indval) of more than $50 \%$ were found for species: Undinula vulgaris (Indval $=85 \% ; p=0.01$ ) and Calanopia americana $($ Indval $=86 \%$; $p=0.03)$.
The Appendicularia Class was the only spatial indicator associated with the combination between stations 3 (Conceição beach) and 5 (Golfinhos Bay) (Indval $=86 \% ; p=0.005$ ).

Cluster analysis for functional features of copepods assemblage showed two main groups (Figure 7): the first composed of broadcast spawners and the second, composed mostly of sac-spawners. Each group is subdivided in two subgroups. Subgroup 1 contained the greater number of species and consisted of calanoid copepods with clearly herbivorous trend predominance. The species of this group contained calanoids with mean body sized of 1300 to $1700 \mu \mathrm{m}$ (Acrocalanus longicornis, Calocalanus pavo, Clausocalanus furcatus, Paracalanus aculeatus and Calanopia americana). Subgroup 2 included fewer species, consisting of larger-sized copepods $(>1700 \mu \mathrm{m})$ as Candacia pachydactyla, Centropages velificatus (both carnivorous) and Undinula vulgaris (herbivorous). Subgroup 3 consisted of copepods with body size of (1110 up to $1300 \mu \mathrm{m}$ ) such as the Calanoida: Euchaeta marina (carnivorous) and the Cyclopoida copepods Agetus flaccus and Corycaeus speciosus. Subgroup 4 was characterized by cyclopoids copepods (Farranula gracilis, Oncaea venusta, Oithona plumifera and Oncaea mediterranea), classified as small omnivores $(<1100 \mu \mathrm{m})$ (exhibiting mixed feeding strategies depending on the availability of food items), and occurring from the epipelagic to the mesopelagic domain of the oceanic environment.

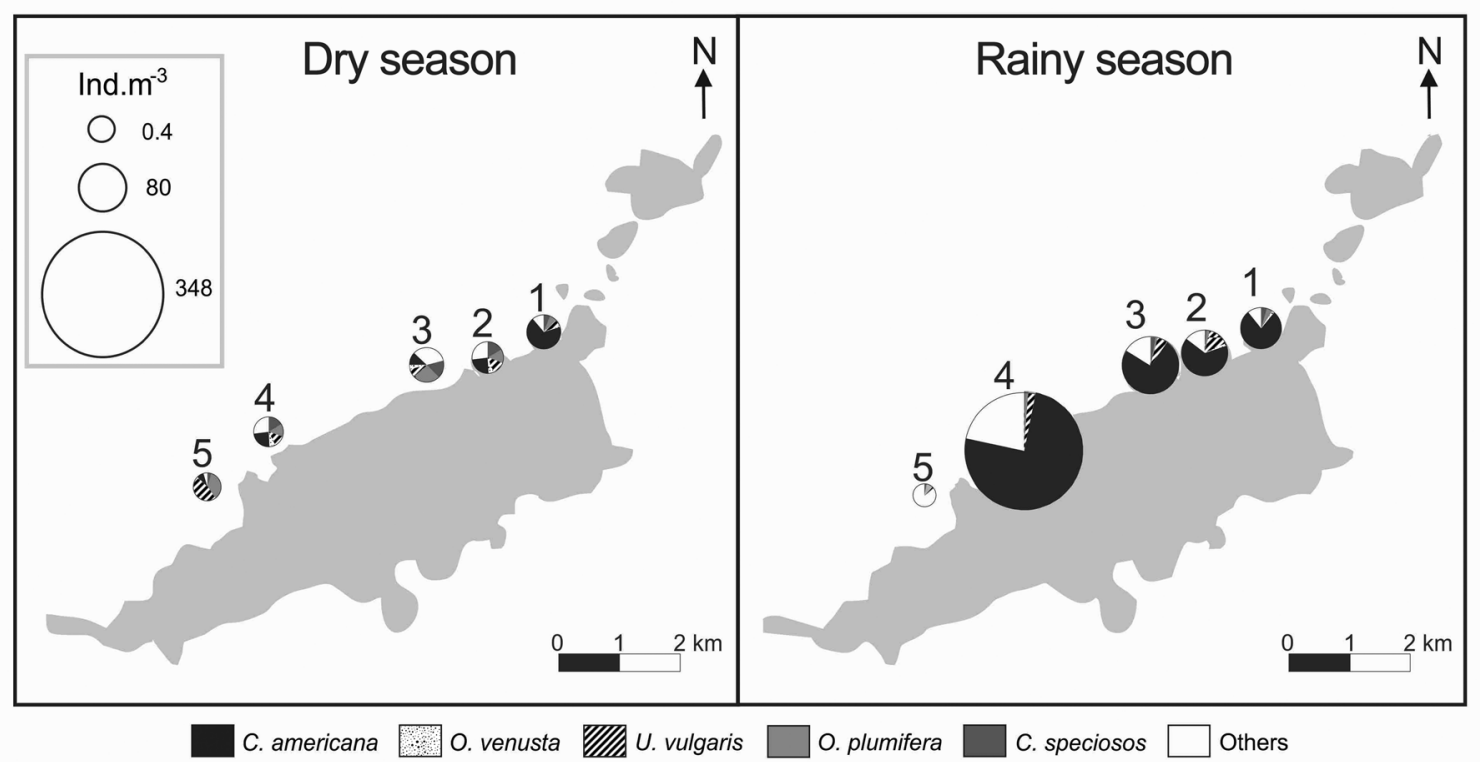

Figure 5. Seasonal (dry and rainy) and spatial (sampling stations) distribution of copepods (Abundance $>2 \%$ ) in: Santo Antônio Port (1), Cachorro Beach (2), Conceição Beach (3), Cacimba do Padre (4) and Golfinhos Bay (5) in the coastal area of the Fernando de Noronha Archipelago in northeastern Brazil. 
Dry season

Aainy season
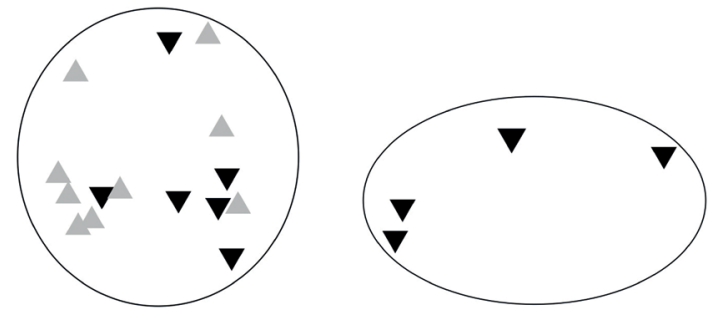

Figure 6. MDS ordination of the mesozooplankton community in response to the seasonal factor: Dry season (Black triangle) and rainy season (Gray triangle) in the coastal area of the Fernando de Noronha Archipelago in northeastern Brazil.

Table 3. Summary of PERMANOVA results for the mesozooplankton community structure of the Fernando de Noronha Archipelago in response to the spatial (as between stations) and seasonal (as between dry $v s$. rainy) factors.

\begin{tabular}{lcccc}
\hline Source & df & MS & Pseudo-F & $p($ perm $)$ \\
\hline $\begin{array}{l}\text { Spatial } \\
\text { (ST) }\end{array}$ & 4 & 2802.8 & 1.012 & 0.483 \\
$\begin{array}{l}\text { Seasonal } \\
\text { (S) }\end{array}$ & 1 & 7102.1 & 2.564 & 0.028 \\
ST x S & 4 & 2239.5 & 0.809 & 0.788 \\
Residual & 9 & 2769.8 & & \\
Total & 18 & & & \\
\hline
\end{tabular}

\section{DISCUSSION}

The study of the abundance, diversity and structure of the mesozooplankton community (with emphasis on copepods) in the years 2013 and 2014 corresponds to the first work carried out in the coastal area of Fernando de Noronha Archipelago, a south-western Atlantic Ocean tropical island. The results indicated a remarkable change in the seasonal distribution of the mesozooplankton community, copepod assemblages and diversity of copepods, but a greater similarity between the quali-quantitative composition was verified between sampling stations, which is explained by the proximity between them.

Previous studies on zooplankton from tropical islands in Brazilian oceanic waters are relatively recent (Cavalcanti and Larrazabal, 2004; Lira et al., 2014), but some have also demonstrated the effect of seasonality on the ecological attributes of the mesozooplankton community (Diaz et al., 2009; Melo et al., 2012). The hypothesis of difference between dry and rainy seasons was verified in the present study, where the mean abundance of mesozooplankton and copepods were significantly higher in the rainy season. Thus, our data suggest a seasonal effect on the ecological attributes of mesozooplankton, but the long-term time series (preferably $>10$ years) is needed to further expand the present findings.

Variations in the meteorological regime, regional geomorphological characteristics and anthropogenic impacts together establish the particular hydrographic regime of each region and, consequently, the taxonomic characteristics and temporal-spatial dynamics of the copepods assemblage (Brandini et al., 1997). Coastal and oceanic epipelagic species of copepods, typical of the tropical and subtropical southwestern Atlantic were identified in the study area, but the numerically dominant species were Calanopia americana, Corycaeus speciosus, Undinula vulgaris and Oithona plumifera. In particular, the species $U$. vulgaris (suspensivore) and C. americana (herbivore) responded significantly to the seasonal factor, presenting high abundance in the rainy season. Both species were considered by the results of the Indval analysis as indicators of the environmental conditions presented in the rainy season on Fernando de Noronha Archipelago.

The distribution of $U$. vulgaris in lagoon systems was positively related to the abundance of organic (particulate) nitrogen sources and abundant food sources may be critical for this species (Renon, 1993). According to Gerber and Gerber (1979) the daily metabolic losses of carbon by $U$. vulgaris are very high, so considerable productivity is required to keep these populations abundant. Therefore, the high, and for that reason, abundance of this specie verified in the rainy season in the present study reinforces an increase of the productivity in "Inner Sea" of FNA during this seasonal period.

Calanopia americana occurs mainly in coastal regions (Bowman, 1971). This species makes vertical migrations in both shallow coastal environments and in deeper locations, being more frequently found in surface waters at night compared to day period (Clarke, 1934; Bowman, 1971; Turner et al., 1979; Cohen and Forward, 2002; Melo et al., 2010; Pessoa et al., 2014). The high abundance of $C$. americana in diurnal samples of FNA could be explained by hydrodynamic effects since the stations are shallow. In addition, the occurrence of swell in some of the sampling periods of the years 2013 and 2014, resuspending bottom sediment and organisms associated with it. Several studies showed the importance of this event in the called surf-zone fauna, where a group of invertebrate species inhabit sandy beach surf zones (Mees and Jones, 1997). This is reforced in our results by the lesser abundance of the C. americana in Golfinhos Bay, a deeper station. 
Table 4. Summary of SIMPER showing the contribution of taxa (abundance $>2 \%$ ) for the differences between the dry and rainy seasons, in the coastal area of Fernando de Noronha Archipelago. The Variable "Taxonomic composition" had a dissimilarity average between dry and rainy seasons of $76.84 \%$.

\begin{tabular}{lccccc}
\hline AR $(\%)>2 \%$ & Rainy Season & Dry Season & & & \\
\hline Taxa & Av.Abund & Av.Abund & Av.Diss & Contrib\% & Cum.\% \\
\hline Calanopia americana & 2.7 & 0.66 & 17.25 & 22.46 & 22.46 \\
Undinula vulgaris & 1.32 & 0.42 & 9.66 & 12.58 & 35.03 \\
Calanoida (Copepodite) & 1.1 & 0.24 & 9.02 & 11.74 & 46.77 \\
Teleostei (eggs and larvae) & 1.08 & 0.19 & 7.91 & 10.29 & 57.07 \\
Farranula gracilis & 1.19 & 0.27 & 7.24 & 9.42 & 66.48 \\
Acrocalanus longicornis & 1.1 & 0.27 & 6.66 & 8.67 & 75.15 \\
Chaetognatha & 0.75 & 0.38 & 6.63 & 8.63 & 83.78 \\
Foraminifera (Others) & 0.64 & 0.63 & 6.45 & 8.4 & 92.18 \\
\hline
\end{tabular}

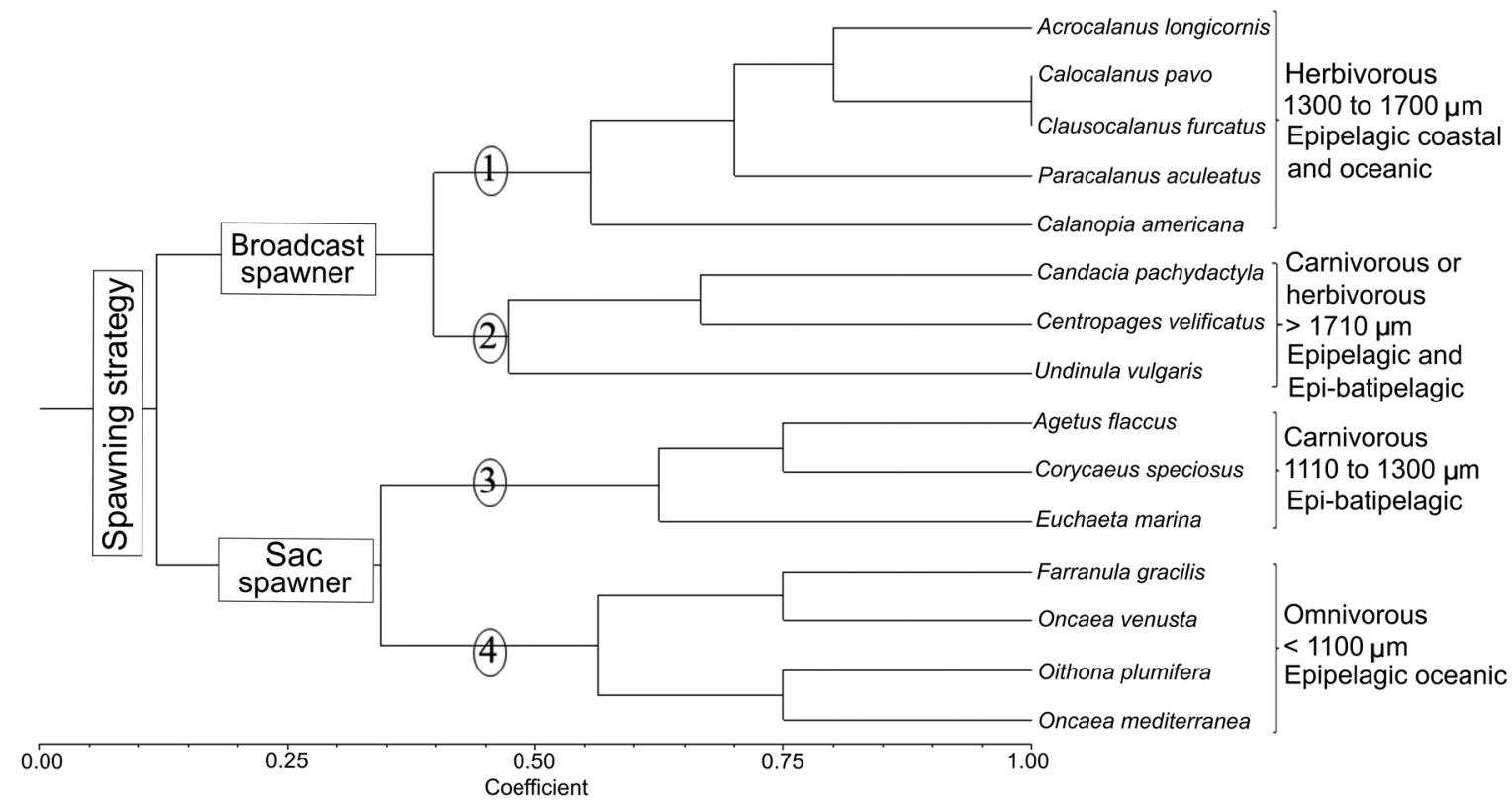

Figure 7. Functional groups of 15 species of copepod identified in the coastal area of the Fernando de Noronha Archipelago based on the Sorensen coefficient and weighted pair group method with averaging clustering method built on four functional characteristics (spawning strategy, trophic group, body size, and vertical distribution).

According to Assunção et al. (2016) the mean precipitation levels recorded for both the years of 2013 and 2014 was higher than usual for the rainy season. The intensification of the hydrological cycle caused salinity reduction, but a water surface heating was identified during the rainy season (June and July) in comparison to dry season. The author also reports that nutrient concentrations exhibited values characteristic of an oligotrophic area, but in general, these values were slightly higher in the rainy season, specifically in the bottom stratum.
Seasonal changes in nutrient concentration are followed by changes in planktonic productivity (Hawes, 1983). The increase in biological productivity in the surrounding islands has been reported in several studies as a consequence of the island mass effect (Doty and Oguri, 1956; Palacios, 2002). Patterns of plankton biomass accumulation or productivity increase near the FNA have been frequently described (Lira et al., 2014; Tchamabi et al., 2017) and related as a consequence of the island effect. Once, "Inner Sea" of FNA is dependent on the region of 
its surroundings where the input of macro and micronutrients from island runoff (Perissinotto et al., 2000) and contributions from benthic processes (Signorini et al., 1999) stand out as the main mechanisms contributing to high productivity during the rainy season. Furthermore, the occurrence of rainfall allows the excrement of seabirds, present in the several elevations (hills) of FNA and especially in the island Rata, (considered the largest deposit of guano and consequent phosphate in Brazil) arrived the waters of the Archipelago more quickly, also contributing to a significant response of planktonic productivity and consequently of the abundance of mesozooplankton and copepods observed in the rainy season in FNA.

In general, the abundance data of mesozooplankton community and copepod assemblages registered for the coastal area of Fernando de Noronha Archipelago are considered low. It is important to emphasize that in the present work, we performed subsurface hauls, with a net of $300 \mu \mathrm{m}$ mesh size. Many researches with Copepoda has shown that the abundance of copepods collected with plankton net using smaller mesh size $(<100 \mu \mathrm{m})$ has nearly two or more orders of degree higher than those obtained with larger mesh size plankton net. These differences are chiefly due to the loss of small-sized copepods in the samples obtained with bigger mesh plankton net (Araujo et al., 2008; Wu et al., 2011). The mean value of the Shannon-Wiener diversity index for copepod assemblages was also considered low in the present study. Significant differences were observed between the seasonal periods investigated, where the mean of season diversity was significantly higher than the values recorded in rainy season. Thus, the lower value recorded for the rainy season can be a consequence of the dominance of the copepods $U$. vulgaris and $C$. americana observed in this seasonal period in the present study. Cavalcanti and Lazzarabal (2004) studying the mesozooplankton of the northeast Brazilian Exclusive Economic zone during the dry season, through oblique hauls with a bongo net (mesh size of $300 \mu \mathrm{m}$ ) in the stratum of $0-200 \mathrm{~m}$, showed that the species diversity of the copepod assemblages presented values ranging from very low to high. The authors explained the fact as a response to the dominance of $U$. vulgaris and $C$. americana in some sampling stations. Then, in order to compare diversity in different environments, considerations must be made regarding the heterogeneity of environments, the sampling effort and the equipment used in sampling (Dias et al., 2010).

\section{FUNCTIONAL FEATURES OF THE COPEPOD} COMMUNITY

In this study two groups were formed according to their reproductive characteristics (broadcast spawner and sac-spawner), and they could be classified in four functional subgroups. Subgroup 1 brought together numerically important calanoids in the epipelagic layer of coastal environments and tropical Atlantic Ocean, some of which, such as $C$. americana, are strong vertical migrants (Neumann-Leitão et al., 2008; Pessoa et al., 2014).

Particularly, C. americana had high participation and dominance in practically all the samples. Peaks of abundance occurred mainly in the rainy season. This fact may have occurred due the intensification of the trade winds in this seasonal period, exhibiting higher intensity from July to September (11 $\mathrm{ms}^{-1}$ ) (Manso et al., 2011). Thus, we suggest that the intensification of the trade winds caused an increase in the intensity of the waves and resuspension of the bottom, considering the benthic habit during the day and planktonic behavior at night of $C$. americana specie (Cohen and Forward, 2002). In several studies that performed daytime sampling this species is cited (Dias and Bonecker, 2009; Dias et al., 2010), but rarely with high abundance (as recorded in the present work). However, high values of abundance have already been recorded for C. americana in nocturnal sampling (Melo et al., 2010; Pessoa et al., 2014). This subgroup also included the Paracalanidae (Acrocalanus longicornis, Calocalanus pavo and Paracalanus aculeatus), a family of great importance in terms of abundance, biomass and daily production, besides being highly adapted to the oligotrophic conditions and having the ability to exploit other forms of food besides the phytoplankton (Miyashita et al., 2009; Melo Júnior et al., 2016). However, in FNA its participation in terms of abudance was low, caused by the selectivity of the plankton net mesh size used $(300 \mu \mathrm{m})$.

The species Candacia pachydactyla, Centropages velificatus and Undinula vulgaris formed the second subgroup within this cluster, composed of larger copepods. Interesting studies of the tropical oceanic zooplankton have shown $U$. vulgaris presenting high values of relative abundance and frequency of occurrence in Northeastern Brazil (Neumann-Leitão et al., 1999; 2008). Candacia pachydactyla and Centropages velificatus together within the subgroup 3 include the carnivorous species. Euchaeta marina, known as among the most common mesozooplankton predators in the planktonic food web, prey on smaller copepods such as Oncaea and Oithona as well as 
the larger Calanoides acutus (Øresland, 1991), doliolids (Takahashi et al., 2013), larvaceans (Ohtsuka and Onbé, 1989) and fish larvae (Yen, 1987); and Corycaeus speciosus and Agetus flaccus which despite being classified as medium-sized carnivores also have the feeding behavior of cruising detritivores, moving to great depths to decompose particulate organic matter and contributing to epipelagic secondary production (Benedetti et al., 2015). Corycaeus speciosus is also typical of the Brazil Current and is an indicator of oligotrophic areas (Björnberg, 1981). This species is very frequent and abundant in oceanic waters with temperatures and salinities around $26^{\circ} \mathrm{C}$ and of 35 , respectively, also having wide tropical and subtropical distribution (Bradford-Grieve et al., 1999).

Subgroup 4 grouped together small marine planktonic copepods (Farranula gracilis, Oncaea venusta, Oncaea mediterranea and Oithona plumifera). Oithona spp. are small, active ambush-feeding omnivores that carry their eggs and has been described as the most ubiquitous and abundant copepod in the world's (Gallienne and Robins, 2001). Oncaea spp. are mainly cruise detritivores, epipelagic and found associated with appendicularians "houses" (Alldredge, 1972; Steinberg et al., 1994). Farranula gracilis is a typical species of the west-central Gulf of Mexico, and of the surface oceanic waters of the Caribbean Sea. It may be associated with the mixed oligotrophic waters of the Caribbean (López-Salgado et al., 2000).

In general, the copepod assemblages of the western coast of Fernando de Noronha Archipelago presented a larger number of species considered as predator-carnivours (Euchaeta marina, Candacia pachydactyla, Corycaeus speciosus, Agetus flaccus, Centropages velificatus and Farranula gracilis). Thus, actual dominance of predator with preference for smaller or larger prey will influence the number of steps in the food chains (number of trophic levels) and thereby determine whether primary production is efficiently passed to larger organisms or remineralized (Hansen et al., 1994).

\section{CONCLUSIONS}

We suggest that changes in the structure of the mesozooplankton community (with emphasis on copepods) of the coastal area of Fernando de Noronha Archipelago ("Inner Sea") was mainly related to the seasonal factor where: (1) The rainy season (considered a period of increased productivity) favored a significant increase in the abundance of mesozooplankton. (2) Undinula vulgaris and Calanopia americana were considered indicators of the environmental conditions presented in the rainy season, recording high values of abundance in this seasonal period. The high abundance of $C$. americana in practically all sampled stations is an evidence of coastal influence, as well it indicates the effects of hydrodynamism inducing the species dominance in all shallow stations, leading to the conclusion that $C$. americana is a key species for the study area. (3) The mean values of Shannon-Wiener diversity of the copepod assemblages indicate a low taxonomic diversity, mainly in the rainy season. This low diversity was explained by the high dominance of $C$. americana and $U$. vulgaris in the samples.

\section{ACKNOWLEDGEMENT}

The authors wish to acknowledge their indebtedness to the Project "Study of the balance of the carbon cycle in the coastal region and its potential transport to the ocean - with emphasis to the Pernambuco coast" (CARECOS) the financial support of the Foundation for Science and Technology Support of Pernambuco (FACEPE/ FAPESP APQ-0074-1.08/11) and the Research Support Foundation of the State of São Paulo (FAPESP/FACEPE/ ANR 2011/50582-0).

\section{REFERENCES}

ALLDREDGE, A. L. 1972. Abandoned larvacean houses: a unique food source in the pelagic environment. Science, 177, 885-887.

ALMEIDA, F. F. M. 1955. Geologia e Petrologia do Arquipélago de Fernando de Noronha, Rio de Janeiro, Instituto Brasileiro de Geografia e Estatística.

ANDERSON, M. J. 2001. A new method for non-parametric multivariate analysis of variance. Austral Ecology, 26, 32-46.

ARAUJO, H. M. P., NASCIMENTO-VIEIRA, D. A., NEUMANN-LEITÃO, S., SCHWAMBORN, R., LUCAS, A. P. O. \& ALVES, J. P. H. 2008. Zooplankton community dynamics in relation to the seasonal cycle and nutrient inputs in an urban tropical estuary in Brazil. Brazilian Journal of Biology, 68, 751-762.

ASSUNÇÃO, R. V., SILVA, A. C., MARTINS, J. \& FLORES-MONTES, M. 2016. Spatial-Temporal Variability of the Thermohaline Properties in the Coastal Region of Fernando de Noronha Archipelago. Journal of Coastal Research, 75, 512-516.

BARTON, A. D., PERSHING, A. J., LITCHMAN, E., RECORD, N. R., EDWARDS, K. F., FINKEL, Z. V., KIØRBOE, T. \& WARD, B. A. 2013. The biogeography of marine plankton traits. Ecology Letters, 16, 522-534.

BENEDETTI, F., GASPARINI, S. \& AYATA, S. D. 2015. Identifying copepod functional groups from species functional traits. Journal of Plankton Research, 38,159-166. 
BJÖRNBERG, T. K. S. 1981. Copepoda. In: BOLTOVSKOY, D. (ed.) Atlas del zooplancton del Atlántico sudoccidental y métodos de trabajos com el zooplancton mariño. Mar del Plata: INIDEP. p. 587-679.

BOLTOVSKOY, D. (ed) 1981. Atlas del Zooplancton del Atlantico Sudoccidental y Métodos de Trabajos con el Zooplancton Marino, Mar del Plata, INIDEP.

BOLTOVSKOY, D. (ed). 1999. South Atlantic zooplankton, Leiden, Backhuys Publishers.

BOWMAN, T. E. 1971. The Distribution of Calanoid Copepods off the Southeastern United States between Cape Hatteras and Southern Florida. Smithsonian Contributions to Zoology, 96, $1-58$.

BRADFORD-GRIEVE, J. M., MARKHASEVA, E. I., ROCHA, C. E. F. \& ABIAHY, B. 1999. Copepoda. In: BOLTOVSKOY, D. (ed.) South Atlantic Zooplankton. Leiden: Backhuys Publishers. p. 869-1098 p.

BRANDINI, F.P.; R.M. LOPES; K.S. GUTSEIT; H.L. SPACH \& R. SASSI. 1997. Planctolologia na plataforma continental do Brasil. Diagnose e revisão bibliográfica. Rio de Janeiro, MMA-CIRM-FEMAR, 196p.

CAVALCANTI, E. A. H. \& LARRAZÁBAL, M. E. L. 2004. Macrozooplâncton da Zona Econômica Exclusiva do Nordeste do Brasil (segunda expedição oceanográfica - REVIZEE/NE II) com ênfase em Copepoda (Crustacea). Revista Brasileira de Zoologia, 21, 467-475.

CLARKE, G. L. 1934. The diurnal migration of copepods in St. George's Harbor, Bermuda. Biological Bulletin, 67, 456-460

COHEN, J. H. \& FORWARD, R. B. JR. 2002. Spectral Sensitivity of Vertically Migrating Marine Copepods. Biological Bulletin, 203, 307-314.

COWIE, R. H. \& HOLLAND, B. S. 2006. Dispersal is fundamental to biogeography and the 805 evolution of biodiversity on oceanic islands. Journal of Biogeography, 33, 193-198

DIAS, C. O. \& ARAÚJO, A. V. 2006. Copepoda. In: BONECKER, S. L. C. (ed.) Atlas de zooplâncton da região central da Zona Econômica Exclusiva brasileira. Rio de Janeiro: Museu Nacional.

DIAS, C. O., ARAUJO. A. V., PARANHOS, R. \& BONECKER S. L. C. 2010. Vertical Copepod Assemblages (0-2300 m) off Southern Brazil. Zoological Studies, 49, 230-242.

DIAS, C. O.; BONECKER, S. L. C. Copepod assemblage (Copepoda, Crustacea) on the inner continental shelf adjacent to Camamu Bay, northeast Brazil. Revista Brasileira de Zoologia, v. 26, p. 629-640, 2009.

DIAZ, X. F. G., GUSMÃO, L. M. O. \& NEUMANN-LEITÃO, S. 2009. Biodiversidade e dinâmica espaço- temporal do zooplâcton. In: VIANA, D. L., HAZIN, F. H. V. \& SOUZA, M. A. C. (orgs.) O arquipélago de São Pedro e São Paulo: 10 anos de Estação Científica. Brasília: SECIRM. p. 128-137.

DOTY, M. S. \& OGURI, M. 1956. The island mass effect. ICES Journal of Marine Science, 22, 33-37.

DUFRÊNE, M. \& LEGENDRE, P. 1997. Species assemblages and indicator species: the need for a flexible asymmetrical approach. Ecological Monographs, 67, 345-366.

FALKOWSKI, P. G., BARBER, R. T. \& SMETACEK, V. 1998. Biogeochemical controls and feedbacks on ocean primary production. Science, 281, 200-206.
FRONTIER, S. Diseño de muestreos. 1981. In: BOLTOVSKOY, D. (ed.) Atlas del zooplancton del Atlántico Sudoccidental y métodos de trabajo con el zooplancton marino. Mar deI Plata: INIDEP. 103-108.

GALLIENNE, C. P. \& ROBINS, D. B. 2001. Is Oithona the most important copepod in the world's oceans? Journal of Plankton Research, 23,1421-1432.

GAUSE, G. F. 1934. The struggle for existence, Baltimore, Williams and Wilkins.

GERBER, R. P. \& GERBER, M. B. 1979. Ingestion of natural particulate organic matter and subsequent assimilation, respiration and growth by tropical lagoon zooplankton. Marine Biology, 52, 33-43.

HANSEN, B., BJORNSEN, P. K. \& HANSEN, P. J. 1994. The size ratio between planktonic predators and their prey. Limnology and Oceanography, 39, 395-403.

HAWES, I. 1983. Nutrients and their Effects on Phytoplankton Populations in Lakes on Signy Island, Antarctica. Polar Bio$\log y, 2,115-126$.

HUTCHINSON, G. E. 1957. Population studies: Animal ecology and demography. Cold Spring Harbour Symposium in Quantitative Biology, 22, 415-427.

KÖEPPEN, W. 1948. Climatologia: Cón un estudio de los climas de la tierra, México, Fondo de Cultura econômica.

LARRAZABAL, M. E., CAVALCANTI, E. A. H., NASCIMENTO VIEIRA, D. A., OLIVEIRA-KOBLITZ, V. S., ARAUJO, E. M., BARRETO, T. M. S. \& NUNES, T. R. S. 2009. Oceanografia biológica: Macro-zooplâncton na ZEE da região Nordeste do Nordeste do Brasil. Parte VII. In: HAZIN, F. H. V. (ed.) Oceanografia Biológica: biomassa primária e secundária, macrozooplâncton, ictioplâncton, ictionêuston, macrofauna bêntica. Sér. Doc. REVIZEE, Score Nordeste. Fortaleza: Martins \& Cordeiro.

LEGENDRE, P. \& LEGENDRE, L. 1998. Numerical ecology. Developments in Environmental Modelling 20, New York, Elsevier.

LIRA, S. M. A., TEIXEIRA, I. A., LIMA, C. D. M., SANTOS, G. S., NEUMANN LEITÃO, S. \& SCHWAMBORN, R. 2914. Spatial and nycthemeral distribution of the zooneuston off Fernando de Noronha, Brazil. Brazilian Journal of Oceanography, 62, 35-45.

LÓPEZ-SALGADO, I., GASCA, R. \& SUÁREZ-MORALES, E. 2000. La comunidad de copépodes (Crustacea) en los giros a mesoescala en el occidente del Golfo de México (julio, 1995). Revista de Biología Tropical, 48, 169-179.

MAFALDA, P. JR, PÉREZ DE RUBÍN, J. \& SAMPAIO DE SOUZA, C. 2007. Mesozooplankton composition and distribution in relation to oceanographic conditions in the Gulf of Cádiz, Spain. Revista UDO Agrícola, 7, 274-284, 2007.

MANSO, V. A., MENOR, E. A., VALENÇA, L. M. M., NEUMANN, V. H. M. L., PEREIRA, N. S, JUNIOR, C. F. A. S. \& SILVA, E. R. M. 2011. Morfodinâmica de praias setentrionais da Ilha de Fernando de Noronha. Revista de Gestão Costeira Integrada, 11, 327-339.

MCARDLE, B. H. \& ANDERSON, M. J. 2001. Fitting multivariate models to community data: a comment on distance based redundancy analysis. Ecology, 82, 290-297.

MEES, J. \& JONES, M. B. 1997. The hyperbenthos. In: ANSELL, A. D., GIBSON, R. N. \& BARNES, M (eds) Oceanography and Marine Biology: An Annual Review. 35. London: UCL Press. 221-255. 
MELO, P. A. M. C., SILVA, T. A., NEUMANN-LEITÃO, S., SCHWAMBORN, R., GUSMÃO, L. M. O. \& PORTO NETO, F. 2010. Demersal zooplankton communities from tropical habitats in the southwestern Atlantic. Marine Biology Research, 6, 530-541.

MELO, P. A. M. C., DIAZ, X. F. G., MACEDO, S. J. \& NEUMANN-LEITÃO, S. 2012. Diurnal and spatial variation of the mesozooplankton community in the Saint Peter and Saint Paul Archipelago, Equatorial Atlantic. Marine Biodiversity Records, 5, 121-135.

MELO-JÚNIOR, M., MARCOLIN, C. R., MIYASHITA, L. K. \& LOPES, R. M. 2016. Temporal changes in pelagic copepod assemblages off Ubatuba, Brazil. Marine Ecology, 37, 877-890.

MIYASHITA, L. K., MELO-JÚNIOR, M. \& LOPES, R. M. 2009. Estuarine and oceanic influences on copepod abundance and production of a subtropical coastal area. Journal of Plankton Research, 31, 815-826.

NEUMANN-LEITÃO, S., GUSMÃO, L. M. O., SILVA, T. A., NASCIMENTO-VIEIRA, D. A. \& SILVA, A. P. 1999. Mesozooplankton biomass and diversity in coastal and oceanic waters off North-eastern Brazil. Archive of Fishery and Marine Research, 47, 153-165.

NEUMANN-LEITÃO, S. N., ESKINAZI-SANTANNA, E. M., GUSMÃO, L. M. O., NASCIMENTO-VIEIRA, D. A., PARANAGUÁ, M. N. \& SCHWAMBORN, R. 2008. Diversity and distribution of the mesozooplankton in the tropical Southwestern Atlantic. Journal of Plankton Research, 30, 795805 .

OHTSUKA, S. \& ONBÉ, T. 1989. Evidence of selective feeding on larvaceans by the pelagic copepod Candacia bipinnata (Calanoida: Candaciidae). Journal of Plankton Research, 11, 869-872.

OMORI, M. \& IKEDA, T. 1984. Methods in marine zooplankton ecology, New York, John Willey.

ØRESLAND, V. 1991. Feeding of the carnivorous copepod Euchaeta antarctica in Antarctic waters. Marine Ecology Progress Series, 78, 41-47.

PALACIOS, D. M. 2002. Factors influencing the island-mass effect of the Galápagos Archipelago. Geophysical Research Letters, 29, 49-1-49-4.

PERISSINOTTO, R., LUTJEHARMS, J. R. E. \& VAN BALLEGOOYEN, R. C. 2000. Biological-physical interactions and pelagic productivity at the Prince Edward Islands, Southern Ocean. Journal of Marine Systems, 24, 327-341.

PESSOA, V. T., MELO, P. A. M. C., MELO JÚNIOR, M. \& NEUMANN-LEITÃO, S. 2014. Population dynamics of Calanopia americana DAHL F., 1894 (COPEPODA, CALANOIDA) in a reef environment in Tropical Brazil. Tropical Oceanography, 42, 24-32.

PIONTKOVSKI, S., WILLIAMS. R., IGNATYEV, S., BOLTACHEV, A. \& CHESALIN. M. 2003. Structural-functional relationships in the pelagic community of the eastern tropical Atlantic Ocean. Journal of Plankton Research, 25, 10211034.
POMERLEAU, S., SASTRI, A. R. \& BEISNER. B. E. 2015. Evaluation of functional trait diversity for marine zooplankton communities in the Northeast subarctic Pacific Ocean. Journal of Plankton Research, 37, 712-726.

RENON, J. P. 1993. Répartition du copépode planctonique Undinula vulgaris (Dana) dans trois types de milieux coralliens. Annales de l'Institut océanographique, 69, 239-247.

RICE, E. \& STEWART, G. 2016. Decadal changes in zooplankton abundance and phenology of Long Island Sound reflect interacting changes in temperature and community composition. Marine Environmental Research, 120, 154-165.

ROBINSON, L. M., ELITH, J., HOBDAY. A. J., PEARSON, R. G., KENDALL, B. E., POSSINGHAM, H. P. \& RICHARDSON, A. J. 2011. Pushing the limits in marine species distribution modelling: lessons from the land present challenges and opportunities. Global Ecology and Biogeography, 20, 789-802.

SARMENTO, V. E SANTOS, P. Trampling on coral reefs: tourism effects on harpacticoid copepods. Coral Reefs 31, pp. 135-146. 2012

SERAFINI, T. Z., FRANÇA, G. B. \& ANDRIGUETTO-FILHO, J. M. 2010. Ilhas oceânicas brasileiras: biodiversidade conhecida e sua relação com o histórico de uso e ocupação humana. Revista da Gestão Costeira Integrada, 10, 281-301.

SIGNORINI, S. R., McCLAIN, C. R. \& DANDONNEAU, Y. 1999. Mixing and phytoplankton bloom in the wake of the Marquesas Islands. Geophysical Research Letters, 26, 3121-3124.

STEINBERG, D. K., SILVER, M. W., PILSKALN, C. H., COALE, S. L. \& PADUAN, J. B. 1994. Midwater zooplankton communities on pelagic detritus (giant larvacean houses) in Monterey Bay, California. Limnology and Oceanography, 39, 1606-1620.

TAKAHASHI, K., ICHIKAWA, T., SAITO, H., KAKEHI, S., SUGIMOTO, Y., HIDAKA, K. \& HAMASAKI, K. 2013. Sapphirinid copepods as predators of doliolids: their role in doliolids mortality and sinking flux. Limnology and Oceanography, 58, 1972-1984.

TCHAMABI, C. C., ARAUJO, M., SILVA, M. \& BOURLÈS, B. 2017. A study of the Brazilian Fernando de Noronha island and Rocas atoll wakes in the tropical Atlantic. Ocean Modelling, 111, 9-18.

TURNER, J. T., COLLARD, S. B., WRIGHT, J. C., MITCHELL, D. V. \& STEELE, P. 1979. Summer Distribution of Ponte1lid Copepods in the Neuston of the Eastern Gulf of Mexico Continental Shelf. Bulletin of Marine Science, 29, 287-297.

WICKSTEAD, J. H. 1979. Zooplancton marino, Barcelona, Ediciones Omega.

WU, C. J., SHIN, C. H. \& CHIANG, K. P. 2011. Does the Mesh Size of the Plankton Net Affect the Result of Statistical Analyses of the Relationship Between the Copepod Community and Water Masses? Crustaceana, 84, 1069-1083.

YEN, J. 1987. Predation by a carnivorous marine copepod, Euchaeta norvegica Boeck, on eggs and larvae of the North Atlantic cod Gadus morhua L. Journal of Experimental Marine Biology and Ecology, 112, 283-296.

ZAR, J.H., 1996. Biostatistical Analysis. 3rd Edn. Prentice Hall Inc., Englewood Cliffs, New Jersey, USA, 1996, 662p 